This manuscript has been submitted for publication in PETROLEUM GEOSCIENCE. Please note that, despite having undergone peer-review, the manuscript has yet to be formally accepted for publication. Subsequent versions of this manuscript may have slightly different content. If accepted, the final version of this manuscript will be available via the 'Peer-reviewed Publication DOI' link on the right-hand side of this webpage. Please feel free to contact any of the authors; we welcome feedback 


\title{
SUBSURFACE EXPRESSION OF A TERTIARY SALT WELD, GULF OF MEXICO
}

\author{
Christopher A-L. Jackson ${ }^{1 *}$ \\ Yue Zhang ${ }^{1}$ \\ Donald A. Herron ${ }^{2}$ \\ Peter J.R. Fitch ${ }^{1}$ \\ ${ }^{1}$ Basins Research Group (BRG), Department of Earth Science and Engineering, \\ Imperial College London, UK \\ ${ }^{2}$ Consultant, Sugar Land, Texas, USA
}

*Corresponding author email: c.jackson@imperial.ac.uk

\begin{abstract}
Salt welds form due to salt expulsion and thinning by mechanical (e.g. salt flow) and/or chemical (e.g. salt dissolution) processes. Despite being ubiquitous in salt-bearing sedimentary basins, where they may trap large volumes of hydrocarbons, little is published on weld thickness and composition. We here use 3D seismic reflection, borehole, and biostratigraphic data from the Atwater Valley protraction area of the northern Gulf of Mexico to constrain the thickness and composition of a tertiary salt weld. Seismic data image an 'apparent weld' (sensu Wagner and Jackson, 2011) at the base of a PlioPleistocene minibasin that subsided into allochthonous salt. Borehole data indicate the weld is actually 'incomplete', being c. $24 \mathrm{~m}$ thick, and containing an upper $5 \mathrm{~m}$ thick halite and a lower $15 \mathrm{~m}$ thick halite, separated by a $4 \mathrm{~m}$ thick mudstone. The age and origin of the intra-weld mudstone is unclear, although we speculate it is either: (i) Late Jurassic, representing material transported upwards from the autochthonous level within a feeder, and subsequently trapped as allochthonous salt thinned and welded, or, perhaps more likely; (ii) Pliocene, representing a piece of salt carapace reworked from the top of and eventually trapped in, the now locally welded sheet. We show that $3 \mathrm{D}$ seismic reflection data may not resolve salt weld thickness, with the presence of relatively thin remnant salt lending support to models of welding based on viscous flow. Furthermore, the halite-dominated character of the weld supports the hypothesis that tectonic purification may occur during salt flow.
\end{abstract}

\section{INTRODUCTION}

Salt welds are ubiquitous in salt-bearing sedimentary basins, forming due to expulsion of salt from 
below or between minibasins (Jackson and Cramez, 1989). Based on their structural position and attitude, welds are described as 'primary' (i.e. subhorizontal, joining strata originally above and below autochthonous salt), 'secondary' (i.e. subvertical, joining minibasins originally situated either side of squeezed and now-evacuated salt diapirs, or 'tertiary' (i.e. subhorizontal, joining strata originally above and below allochthonous salt (Jackson and Cramez, 1989). Depending on how much salt they contain (or are inferred to contain), welds are also described as 'complete' (i.e. contains no remnant salt; cf. Jackson and Cramez, 1989), 'incomplete' (i.e. contains up to $50 \mathrm{~m}$ of remnant salt), 'discontinuous' (i.e. contains complete and incomplete parts), or 'apparent' (i.e. appears free of salt at a particular scale of observation (Wagner, 2010; Hudec and Jackson, 2011; Wagner and Jackson, 2011; Rowan et al., 2012; Jackson et al., 2014).

Salt welds are economically important because, depending on their thickness and composition, they may represent barriers to fluid flow, and thus trap hydrocarbon accumulations (Rowan, 2004). Furthermore, weld thickness and composition reveal much about salt rheology and patterns of internal deformation (see below; see also Kupfer, 1968; Wagner and Jackson, 2011; Jackson et al., 2014). Despite their importance and ubiquity, we have a rather poor understanding of the thickness or composition of subsurface welds; in some basins, this reflects a lack of borehole penetrations or, in relatively densely drilled basins, such as the Gulf of Mexico, restricted access to the related borehole data. Where these data are available, such as in the Santos Basin, offshore Brazil they indicate that even high-quality $3 \mathrm{D}$ seismic reflection data may be unable to resolve the thickness or composition of welds. Borehole data also show that primary welds may lack true 'salt' (e.g. halite and potash), and instead contain carbonate, anhydrite, and sandstone (Jackson et al., 2014; see also fig. 17 in Wagner and Jackson, 2011). This lithological partitioning suggests preferential expulsion of the more mobile halite and potash salt from the autochthonous layer into flanking diapirs during viscous flow and welding, and/or preferential dissolution of these components, which, in addition to being the most mobile, are also the most soluble. This process, which is termed 'differential purification by movement' by Kupfer (1968), implies that successive periods of salt flow, for example as salt ascends from autochthonous to allochthonous levels, will lead to relative enrichment in the more mobile components (e.g. halite, potash salts) of the original salt layer. This observation supports analytical and numerical models based on viscous-thinning of the salt during welding (Wagner and Jackson, 2011), which conclude it is difficult to fully remove salt from a weld by viscous flow alone because of boundary drag along the salt contacts (see also Cohen and Hardy, 1996; Hudec and Jackson, 2007). More specifically, the models of Wagner and Jackson (2011) suggest that a weld may contain anywhere from $<1 \mathrm{~m}$ to up to c. $50 \mathrm{~m}$ of remnant salt, although they recognize that model-based predictions of remnant evaporite thickness in salt welds has hitherto been difficult to test due to a lack of data from natural welds (see Wagner, 2010; Hoetz et al., 2011; Liro and Holdaway, 2011; Rowan et al., 2012). 
We here use 3D seismic reflection, borehole and biostratigraphic data from Block 8 in the Atwater Valley protraction area of the Gulf of Mexico (Fig. 1) to characterise the subsurface expression of a tertiary salt weld. 3D seismic reflection data allow us to define the geophysical expression and structural context of the weld, whereas borehole data allow us to constrain weld thickness and composition. Biostratigraphic data allow us to establish the age of weld-flanking strata, and to place the development of the weld in the regional salt-tectonic framework. More specifically, our data allow us to test the following two hypotheses: (i) that allochthonous salt, and laterally equivalent tertiary welds, should be relatively enriched in the more mobile lithologies typically encountered at autochthonous levels; and (ii) that only several tens of metres of remnant salt should remain in a seismically defined weld. We then discuss the implications of our results for petroleum systems development in salt-influenced sedimentary basins.

\section{GEOLOGICAL SETTING}

The Gulf of Mexico formed in response to Triassic-Early Cretaceous rifting (e.g., Pindell and Dewey, 1982; Kneller and Johnson, 2011; Hudec et al., 2013b). Extension and subsidence allowed establishment of a restricted marine seaway, within which the Louann salt (Middle Jurassic) was deposited (e.g., Hazzard et al., 1947; Humphris, 1978; Salvador, 1987; Kneller and Johnson, 2011; Hudec et al., 2013a). Since then, in the northern Gulf of Mexico, this salt layer flowed to form a complex array of salt diapirs and sheets, canopies and welds, largely in response to loading of the autochthonous and then allochthonous salt levels by Mesozoic to Cenozoic sediments, now preserved in predominantly clastic-filled minibasins (Fig. 1B) (e.g., Diegel et al., 1995; Peel et al., 1995; Rowan, 1995; Pilcher et al., 2011).

Our study area is located in Block 8 of the Atwater Valley protraction area, on the south-western flank of the Mississippi Fan, northern Gulf of Mexico (Fig. 1). Water depths range from 650 to $1150 \mathrm{~m}$. Here, the salt-tectonic framework is dominated by: (i) Miocene and older rocks contained in primary minibasins that overlie autochthonous salt; (ii) a series of diapiric feeders that separate primary minibasins, and that connect upward to feed salt sheets within a regionally extensive canopy extending southwards to the Sigsbee Escarpment; and (iii) Plio-Pleistocene rocks contained in secondary minibasins that subsided into allochthonous salt and that locally welded to underlying primary minibasins (Fig. 1B).

\section{DATASET}

\section{Seismic Data}


The seismic volume used in this study is a subset of a large regional 3D survey, composed of multiple narrow-azimuth 3D seismic data sets acquired in 1995-1998 and subsequently reprocessed as a single survey in 2008. This subset covers an area of approximately $550 \mathrm{~km}^{2}$ in the southwestern Mississippi Canyon (MC) and northwestern Atwater Valley (AT) protraction areas in the east-central Gulf of Mexico (Fig. 1A). 3D Kirchhoff prestack depth migrated (KPSDM) data migrated using an isotropic velocity model, with a sample rate of $10 \mathrm{~m}$, record length of $15 \mathrm{~km}$, and final bin size of $25 \mathrm{~m} \times 25 \mathrm{~m}$, were used for interpretation. The data were processed to zero phase, and all seismic displays in this paper follow a polarity convention in which, for a zero-phase wavelet, a positive reflection coefficient and downward increase in acoustic impedance is represented by a central trough (plotted white on a variable-density display).

\section{Borehole Data}

We used data from exploration borehole AT-8 \#1 ST, which was drilled in 1997 in the eastern part of the study area (Fig. 2). The borehole penetrated clastic overburden within a supra-salt, secondary minibasin, before penetrating the studied weld and terminating in underlying clastic rocks within the underlying, sub-salt, primary minibasin (minibasin terminology after Pilcher et al., 2011). Conventional borehole measurements include differential caliper, bulk density, sonic, gamma ray and neutron porosity, which together allowed us to interpret the lithology of the weld, and the sub- and suprasalt strata. Biostratigraphic data were also available in this borehole, allowing us to constrain the age of strata above and below the weld.

\section{METHODOLOGY}

\section{Well-to-Seismic Tie and Seismic Interpretation}

We mapped three key seismic horizons; (i) base allochthonous salt; (ii) top allochthonous salt; and (iii) seabed (Figs 3). By mapping base allochthonous salt we were able to identify structural lows at the base of the sheet, which may represent feeders (Fig. 3A; see also Supplementary Material 1) (see Jackson and Hudec, 2017). Mapping top (Fig. 2B) and base (Fig. 2A) salt allowed us to construct a salt isopach (Fig. 2C), from which we identified areas of thin or welded salt. An overburden isopach, generated from our top salt and seabed maps, revealed the location of secondary minibasins and their relationship to the identified salt weld (Fig. 2D).

\section{Well-log Interpretation}

We established the thickness and composition of the salt weld via petrophysical analysis of wireline log 
data (cf. Jackson et al., 2014). We used a combination of logs to broadly differentiate between: (i) relatively coarse-grained, likely sandstone-prone lithologies; (ii) relatively fine-grained, likely mudstone-dominated lithologies; and (iii) non-clastic lithologies (e.g. evaporites) (Figs 4 and 5) (Rider and Kennedy, 2011). We show that halite is characterised by relatively low GR (60 - 75 API) and neutron porosity (p.u.) (0.1-0.3, with the majority clustering around c. 0.19$)$ values, low-to-moderate DT values $(101-125 \mu \mathrm{s} / \mathrm{ft})$, and low RHOB values $\left(1.99-2.11 \mathrm{~g} . \mathrm{cm}^{-3}\right)$. The anomalously high DT values for halite, which are more typically $65-75 \mu \mathrm{s} / \mathrm{ft}$, may reflect poor hole conditions at this level, an interpretation supported by the pronounced increase in the caliper change values from c. 0.5 inch within the overlying and underlying clastics, to $>1$ inch within the upper and lower halite (Fig. 4B). An alternative interpretation is that the halite is strongly 'polluted' by acoustically faster clastic material, although we consider this unlikely given the halite retains neutron porosity values (p.u.) considerably less than that of encasing clastic rocks (see below) (Fig. 5). Sandstone above and below the salt is also characterised by low GR values (50 - 70 API) but has moderate DT $(110-130 \mu \mathrm{s} / \mathrm{ft})$, RHOB (1.99 2.23 g. $\left.\mathrm{cm}^{-3}\right)$, and neutron porosity (p.u.) (0.26-0.5) values. Mudstone, despite having broadly similar and neutron porosity (p.u.) (0.26-0.55) values, is differentiated from sandstone based on its relatively high GR (50 - 110 API), moderate-to-high DT (116 - $130 \mu \mathrm{s} / \mathrm{ft})$, and relatively high RHOB (2.14 $2.31 \mathrm{~g} . \mathrm{cm}^{-3}$ ) values. We used the caliper log to identify poor borehole conditions, which may signify intervals of strata deformed due to flow of salt (left-hand log track in Fig. 4A and B) (cf. Hilchie, 1968; Theys, 1999).

\section{Biostratigraphic Analysis}

We calibrated biostratigraphic data from AT-8 \#1 ST (Fig. 6; see also Supplementary Material 2) to the biostratigraphic chart of the Gulf of Mexico Offshore Region, provided by the Bureau of Ocean Energy Management, Regulation and Enforcement from the United States Department of Interior (https://www.data.boem.gov/Paleo/Files/biochart.pdf; webpage accessed $15^{\text {th }}$ November 2017; see also Supplementary Material 3). This chart covers regional and local markers, foraminiferal, planktonic and benthic markers, in addition to regional and local calcareous nannoplanktonic markers, spanning the Jurassic to Quaternary.

\section{SEISMIC ANALYSIS OF THE SALT-TECTONIC STRUCTURE}

Here we provide a brief description of the salt-tectonic structure of the study area and the structural context of the weld, focusing on three main structural units: (i) sub-salt minibasins; (ii) allochthonous salt; and (iii) supra-salt minibasins.

\section{Sub-salt Minibasins}


Due to migration noise and residual multiples generated by overlying allochthonous salt, sub-salt minibasins are not well imaged in our seismic data. Locally, however, where overlying salt is relatively thin, we observe relatively continuous, variable amplitude, sub-horizontal to gently dipping reflections (Fig. 3). These reflections are truncated below allochthonous salt (or its equivalent weld; see below) across a base salt unconformity that is typically steepest near inferred feeders (labelled ' $F$ ' in Fig. 3; see also below). In the northeastern part of the study area, immediately north of AT-8 \#1 ST, gently south-dipping strata within a sub-salt minibasin are truncated northward below more steeply dipping strata in a secondary minibasin; we interpret the contact between these two minibasins as a secondary weld (labelled 'S' in Fig. 3E) (sensu Jackson and Cramez, 1989). AT-8 \#1 ST penetrates the upper c. $1832 \mathrm{~m}$ of a sub-salt minibasin beneath supra-salt minibasin 5; well-log (Fig. 4) and biostratigraphic data (Fig. 6) indicate the sub-salt basin contains a conformable succession of Late Miocene (Messinian) to Late Pliocene (Gelasian) deep-water clastics.

\section{Allochthonous Salt}

Several allochthonous salt bodies are present within the study area. The tops and bases of these bodies are characterised by regionally mappable, high-amplitude trough (downward increase in acoustic impedance) and peak (downward decrease in acoustic impedance) reflections, respectively. The salt is itself characterised by very chaotic, low-amplitude reflections (Figs 3 and 7). The main allochthonous salt body is up to $5500 \mathrm{~m}$ thick, broadly $\mathrm{U}$-shaped within the area imaged by our seismic data, and encircles at least the southern end of the minibasin penetrated by AT-8 \#1 ST (Fig. 2C). Base salt is very rugose, being defined by at least five sub-circular structural lows that are up to $8 \mathrm{~km}$ in diameter and with up to $2 \mathrm{~km}$ of relief (Figs 2A and 3); although subsalt seismic imaging is poor, based on (i) their geometric similarity to features observed elsewhere in the Gulf of Mexico (e.g. Pilcher et al., 2011); (ii) their development at the base of a large allochthonous salt body; and (iii) their development adjacent to clearly truncated sub-salt strata, we interpret these features as the tops of diapiric feeders that rose from autochthonous levels, between and thus defining the sub-salt minibasins, and which fed the overlying allochthonous salt canopy (Jackson and Hudec, 2017). Allochthonous salt appears to be locally welded beneath the northern part of minibasin 5 (Fig. 2D); we describe the geophysical expression, and thickness and composition of this weld below. Apart from an anomalous, biostratigraphically defined age-relationship immediately above it (see detailed description below), the salt is immediately underlain and overlain by Early Pleistocene (Gelasian) strata, constraining sheet emplacement to this time (Fig. 6).

\section{Supra-salt Minibasins}


At least five supra-salt minibasins, which are up to $12 \mathrm{~km}$ wide and $6.5 \mathrm{~km}$ thick, overlie the allochthonous salt (i.e. minibasins 1-5) or its equivalent tertiary weld (i.e. northern part of minibasin 5) (see labels in Fig. 2D). Biostratigraphic data indicate an overall downward increase in sediment age within minibasin 5, with Holocene strata passing downwards into earliest Pleistocene (Gelasian) strata (Fig. 6). However, we note an anomalous age-depth relationship in the interval 4359-4394 m, just above the salt weld we describe further below. Here, a c. 34 m thick interval of anomalously old, Zanclean (4377 and $4394 \mathrm{~m}$ ) to Piacenzian (4359 m) strata, which is logically overlain by younger, Gelasian strata, is also underlain, beneath the weld, by younger, Gelasian strata (e.g. samples at 4526 and 4599 m) (Fig. 6). The significance of this anomalous age-depth relationship is discussed further below in the context of the temporal evolution of the studied weld.

\section{BOREHOLE EXPRESSION OF THE WELD AND SUPERJACENT STRATA}

A salt weld, which we will later show is 'apparent', at least where penetrated, (terminology after Wagner and Jackson, 2011; see also Jackson et al., 2014), is developed in the east-central part of the study area, beneath minibasin 5 (Fig. 2E, 3B and E). The seismic expression of the weld should, at least theoretically, be similar to that of surrounding salt bodies (i.e. defined by an upper, trough reflection defining a downward increase in impedance between clastic rocks in a suprasalt minibasin and halite, and a lower, peak reflection defining a downward transition from halite into clastic rocks in the underlying subsalt minibasin; Fig. 7; see also P-wave log in Fig. 4 and data in Fig. 5). However, because it is relatively thin ( $24 \mathrm{~m}$; see below) compared to the vertical resolution of the seismic data, it is difficult to correlate the top and base of the weld to, or confidently map its stratigraphic position based on, discrete reflection events. Instead, the approximate position of the weld is based on: (i) the position of halite in AT-8 \#1 ST; (ii) the location of the top and base salt reflection where the unit is substantially thicker in salt sheets flanking the minibasin 5; and (iii) the upward transition from relatively discontinuous, locally chaotic reflections below to more continuous reflection above (Fig. 7). The highly variable seismic expression of the weld likely reflects lateral variations in weld thickness, and the composition (and thus acoustic properties) of underlying and overlying clastic rocks.

Immediately adjacent to AT-8 \#1 ST, the weld dips $c .28^{\circ}$ southward and is thus conformable with underlying and overlying, broadly south-dipping reflections (Figs 3E and 6B). Directly below the weld, a c. $180 \mathrm{~m}$ thick package of relatively discontinuous, locally chaotic reflections is present, which is underlain by more continuous reflections (Fig. 7). North of AT-8 \#1 ST, the weld dips northward, ultimately connecting to a moderately northward-dipping $\left(c .30^{\circ}\right)$ secondary weld separating two primary minibasins (labelled ' $\mathrm{S}$ ' in Figs 3E and 7B). East and west of AT-8 \#1 ST, the weld connects to the two allochthonous salt bodies (Fig. 3B). 
AT-8 \#1 ST penetrates the central part of minibasin 5 and its underlying weld (Figs 2E, 3B, 3E, and 7). Well-log data allow us to constrain the petrophysical expression, thickness and composition of the weld at this position (Fig. 4). At the approximate depth of the weld, as defined by our seismic mapping, and tied to well control using a regional anisotropy-depth function for correction of seismic depths to well depths, well log data indicate two anomalously low density, high neutron, low gamma ray intervals are present, separated by a $4 \mathrm{~m}$ thick mudstone (4412-4436 m; Fig. 4B). These upper and lower, anomalously low-density intervals, which are $5 \mathrm{~m}$ and $15 \mathrm{~m}$ thick respectively, plot toward the top-left of a standard neutron-density crossplot (the purple and pink points in Fig. 5), thus are petrophysically and, we infer below, compositionally distinct from the over- and underlying, clastic-dominated sequences. We also observe significant increases in the resistivity log measurements in these intervals (4-16 ohm.m; Fig. 4A), in addition to a relative increase in the 'change in caliper' measurement, which implies a 'softer' lithology that caused enlargement of the borehole during drilling (between 4412-4416 and 4425-4436 m; Fig. 4B).

Based on its well log signature, in addition to our understanding of the broader salt-tectonic framework of the northern Gulf of Mexico, we interpret the petrophysically distinct intervals encountered between 4412-4436 m contain halite. An alternative interpretation is that these intervals represent gas-bearing clastic rocks; however, we dismiss this interpretation based on the absence of gas indicators at deeper or shallower levels within the borehole. It is important to note that no biostratigraphic data were recovered in this interval, thus the age of the intra-weld mudstone is unknown.

Our petrophysical analysis indicates the $c .180 \mathrm{~m}$ thick package of discontinuous seismic reflections directly below the weld is mudstone-dominated, having similar petrophysical characteristics to shallow and deeper mudstones (i.e. relatively high gamma-ray, high density and moderate porosity; Figs 4 and $5)$.

\section{INTERPRETATION AND DISCUSSION}

\section{Salt-tectonic context of the weld}

The studied salt weld forms part of a regionally extensive salt canopy sourced from deep (Jurassic) Louann salt, lying within the 'amalgamated salt-stock-canopy province' of Pilcher et al. 2011 (Fig. 1B). Previous regional studies suggest canopy emplacement in Atwater Valley occurred during the Middle to Late Miocene, most likely in response to regional shortening and the extrusion of salt from diapiric feeders (Peel et al., 1995). However, our new data, more specifically our observation that the weld and laterally equivalent canopy of inflated salt overlie Early Pleistocene (Gelasian) strata (Fig. 6), suggest canopy emplacement, at least in this part of Atwater Valley, was considerably later (i.e. Early 
Pleistocene). The difference in timing of canopy emplacement to that suggested by Peel et al. (1995) and presented here may reflect: (i) our access to higher-quality seismic reflection and biostratigraphic data, with the latter in particular providing tighter age constraints on the age of sub- and suprasalt strata; and (ii) the fact that canopy emplacement is indeed protracted, with initial diapir breakout and spreading occurring in some areas during the Middle to Late Miocene, but with the canopy not reaching our study area until the Early Pleistocene, several millions years later.

In detail, the age-depth relationship associated with the weld, where Zanclean (early Pliocene) and Piacenzian (late Pliocene) strata just above the weld are encased in younger, Early Pleistocene (Gelasian) strata, is anomalous (Fig. 6). In the absence of a salt weld and its laterally adjacent sheets, we might simply interpret this age inversion to indicate erosion and redeposition of Pliocene strata within younger Pleistocene strata. However, given its structural and stratigraphic association with allochthonous salt, we can refine this interpretation and suggest the Pliocene strata were initially deposited as part of a thin roof capping the canopy, during and after break-out from one or more of its feeders, before being eroded and redeposited within younger Pleistocene strata.

The age and origin of the $4 \mathrm{~m}$ thick, intra-weld mudstone, which, despite being thin, accounts for $17 \%$ of the total weld fill, may also be explained by a similar mechanism to that responsible for the supraweld age inversion. In this case, the mudstone initially represented relatively young (i.e. Pliocene) 'carapace' (i.e. a relatively thin layer of sediment) material carried atop an advancing salt sheet, later being trapped as the sheet welded. The mudstone was then overridden by salt from the same or different sheet, which itself was then thinned and welded. An alternative interpretation is that the mudstone is much older. For example, it could be the same age as the salt (i.e. Jurassic), having ascended from autochthonous levels within a feeder before being reworked from atop or trapped within an advancing salt sheet that eventually welded.

\section{The geophysical and geological expression of salt welds}

We have shown that good quality seismic reflection data can constrain the gross position of a subhorizontal tertiary salt weld. Seismic data alone do not, however, constrain the completeness or composition of the weld studied here, with borehole data indicating a few tens of metres of halitedominated stratigraphy (cf. Jackson et al., 2014). Interpreting a complete weld, or the composition of an incomplete weld may, therefore, be extremely challenging in the absence of borehole data; incomplete welds might be erroneously interpreted as being complete, when in reality, a thin veneer of impermeable rock remains between adjacent country rocks. The results of our study support the recommendation of Jackson et al. (2014), who suggested that, until borehole data unequivocally demonstrate the absence of evaporite between flanking strata, the term 'apparent weld' be used to 
describe seismically defined welds.

Our observation that a c. $20 \mathrm{~m}$ thick sequence remains in the Atwater Valley salt weld is consistent with the predictions of analytical and numerical models presented by Wagner and Jackson (2011), which suggest natural salt welds formed by viscous flow alone may contain anywhere from $\ll 1 \mathrm{~m}$ to up to $\mathrm{c}$. $50 \mathrm{~m}$ of remnant salt. Our data, and that from the Campos (Wagner and Jackson, 2011) and Santos basins (Jackson et al., 2014), thus support the hypothesis of Wagner and Jackson (2011) that viscous flow is a good analytical approximation of the physical processes occurring during salt thinning and welding, but that viscous flow alone is unlikely to result in complete evacuation of a salt layer. However, it is important to note that a borehole, irrespective of the quantity and quality of data it provides, is only a 1D sample point; it is of course possible that, away from this sample point, the weld may be locally complete.

\section{Composition of salt welds}

Our borehole data indicate the incomplete tertiary weld penetrated by AT- 8 \#1 ST is dominated by halite, and that other evaporite (e.g. anhydrite, potash salts) and non-evaporite lithologies, such as carbonate, are absent (Figs 4 and 5). The composition of the weld differs strongly to that encountered in primary welds in other salt-bearing sedimentary basins. For example, the Parati Weld, Santos Basin, offshore SE Brazil, which is $22 \mathrm{~m}$ thick, is halite-poor, being dominated by carbonate (40\%) and anhydrite (40\%), with minor amounts of sandstone (16\%) and marl (4\%). Similarly, halite-poor sequences are observed in incomplete primary welds penetrated by boreholes in the Campos Basin, offshore Brazil (see fig. 17 in Wagner and Jackson, 2011). In that location, 75 boreholes have penetrated multi-layered evaporites in the Retiro Member of the Lagoa Feia Formation (Aptian) (or its nonmarine equivalent). Forty-one of these boreholes penetrate evaporite-bearing sequences that are $<100 \mathrm{~m}$ thick; of these, only 10 boreholes contain halite and anhydrite, with the remaining 31 boreholes containing only anhydrite.

The compositional variability encountered in salt welds may reflect several factors, such as compositional variations in the autochthonous salt or preferential dissolution of more soluble salts (e.g. halite and bittern salts). For example, autochthonous salt comprising solely halite will yield only halite welds, regardless of structural position within the salt-tectonic system (e.g. primary, secondary and tertiary). Such a case has been informally proposed for the Gulf of Mexico. However, in cases where the autochthonous salt is demonstrably heterogeneous, variations in weld composition may instead reflect a rheological and, ultimately, compositional control on the rate and degree of expulsion of different lithologies during salt thinning. For example, low viscosity, more mobile lithologies, such as halite and potash salt, occurring in thick autochthonous salt in sufficiently large quantities, may be 
preferentially expelled from thinning salt before relatively high viscosity, less mobile lithologies, such as carbonate, anhydrite and sandstone. As such, during welding, salt becomes relatively enriched in these less mobile, non-halite/potash salt lithologies, which, due to the effects of boundary drag along the upper and lower salt contacts, becomes trapped in the weld as the salt thinned (compare 'differential purification by movement'; Kupfer, 1968; see also Wagner and Jackson, 2011 and Jackson et al., 2014). Salt structures flanking welds, be they diapirs or autochthonous bodies, should thus be relatively enriched in mobile halite and potash salts, and lack non-halite lithologies; this hypothesis is directly proven by borehole data (Jackson et al., 2014; 2015), and at least given some indirect support from seismic facies analysis (Van Gent et al., 2011; Fiduk and Rowan, 2012; Strozyk et al., 2012).

The differential purification by movement model, which only applies to compositionally heterogeneous systems, suggests increasing compositional fractionation of salt should occur as the salt-tectonic system evolves; more viscous, less mobile, and/or denser units are typically stranded within the autochthonous level, trapped in primary welds, or stranded near the basal root of diapirs, whereas less viscous and/or less dense units form the cores of these diapirs and, potentially, genetically related, allochthonous sheets and canopies. As such, supra-sheet minibasins forming above allochthonous salt sheets or canopies should subside into 'purer' salt dominated by halite and potash salts and, accordingly, underlying tertiary welds should be relatively rich in these rock types. Our data support this model, with a haliterich weld being observed at relatively shallow levels in this salt-tectonic system. However, due to a lack of deep borehole data and post-depositional salt flow, we do not know the composition of autochthonous salt in the Gulf of Mexico, thus we cannot prove the halite-rich nature of the weld described here simply reflects strain-induced compositional fractionation.

Observations from exposed salt-tectonic systems show that the structurally shallow levels of some diapirs may contain very large (i.e. up to several kilometres in diameter) clasts of rock clearly denser than the encasing salt (e.g. igneous rock, anhydrite; Dalgano and Johnson, 1968; Kent, 1979; RichterBernberg, 1980; Gansser, 1992; Lawton and Amato, 2017). These clasts were carried up several kilometres from autochthonous levels within the rising salt and have not yet sunk, with numerical and physical models indicating this occurs because salt rise rate exceeds the descent rate of the denser clast (e.g. Koyi \& Schott, 2000; Koyi, 2001; Chemia et al., 2008). Observations from natural examples, and numerical and physical models thus challenge the 'differential purification by movement' model, showing that rheology alone may not control vertical changes in composition within salt-tectonics systems. More specifically, numerical models suggest that sedimentation rate, salt viscosity, diapir width, and stratigraphic position of the dense layer within the initial autochthonous layer may also control the ability of rising salt to entrain, transport, and suspend relatively dense clasts (Chemia et al., 2008). 


\section{Implications for petroleum systems development in salt basins}

This observation, along with the fact that various lithologies may remain in an incomplete weld, may directly impact hydrocarbon prospectivity in salt-tectonic basins. For example, the sealing capacity of an incomplete weld containing very low-permeability halite is likely to be higher than an incomplete weld containing permeable layers of carbonates and clastics. We may therefore speculate that primary welds, which may contain relatively little low-permeability halite and thus higher proportions of more permeable non-evaporitic lithologies, may be poorer seals and thus more susceptible to leakage. Additional data from primary, secondary, and tertiary welds, in addition to information on the hydrocarbon presence (or absence) in sub-salt strata, is required to test this hypothesis.

\section{CONCLUSIONS}

3D isotropic Kirchhoff prestack depth migrated (KPSDM) seismic data image the salt-tectonic structure and reveal the geophysical expression of a tertiary salt weld in the Atwater Valley protraction area of the Gulf of Mexico. This weld formed at the base of a Plio-Pleistocene minibasin that subsided into a thick allochthonous salt canopy fed by several diapiric feeders. Seismic reflection data suggest the weld is devoid of salt and is thus 'complete', although borehole data demonstrate the weld is in fact 'incomplete', being c. $24 \mathrm{~m}$ thick and containing an upper $5 \mathrm{~m}$ thick halite and a lower $15 \mathrm{~m}$ thick halite, separated by a $4 \mathrm{~m}$ thick mudstone. The origin and age of the intra-weld mudstone is unclear; it may be Late Jurassic, representing material transported upwards from the autochthonous level within a feeder, or Pliocene, representing carapace material incorporated into the canopy prior to thinning and welding. We show that even relatively modern 3D seismic reflection data may not resolve salt weld thickness, with the presence of a relatively thin layer of salt supporting analytically derived models of welding based on viscous flow. Furthermore, the halite-dominated character of the weld supports the hypothesis that tectonic purification occurs during flow of salt from autochthonous to allochthonous levels. In terms of hydrocarbon exploration, understanding the thickness and composition of material left in salt welds is important, with data presented here and in other studies suggesting that, for the same given thickness, the seal potential of tertiary welds may be higher than that of primary (or secondary) welds due to them being relatively enriched in low-permeability halite.

\section{ACKNOWLEDGEMENTS}

We thank Petroleum Geo-Services (PGS) for permission to use and show their proprietary seismic data, and Schlumberger for providing Petrel software to Imperial College via an Academic License Agreement. Biostratigraphic data for the AT-8 \#1 ST were provided by Lexco Data Systems, L. P. in conjunction with Petroleum Geo-Services (PGS). Thomas Hearon and two anonymous reviewers are 
thanked for helpful comments that improved the final manuscript. We also thank Bruce Trudgill for his editorial handling, as well as Mike Hudec, Yikuo Liu, and Connor O’Sullivan for very helpful discussions during the course of this study.

\section{REFERENCES}

Chemia, Z., Koyi, H., and Schmeling, H, 2008, Numerical modelling of rise and fall of a dense layer in salt diapirs: Geophysical Journal International, 172, 798-816.

Cohen, H.A., and S. Hardy, 1996, Numerical modelling of stratal architectures resulting from differential loading of a mobile substrate, in G.I. Alsop, D.J. Blundell, and I. Davison, eds., Salt tectonics: Geological Society London Special Publications, 100, 265-273.

Dalgarno, C.R., and Johnson, J.E., 1968, Diapiric structures and late Precambrian-Early Cambrian sedimentation in the Flinders Ranges, South Australia: American Association of Petroleum Geologists Memoir, 8, 301-314.

Diegel, F. A., J. F. Karlo, D. C. Schuster, R. C. Shoup, and P.R. Tauvers, 1995, Cenozoic structural evolution and tectono-stratigraphic framework of the northern Gulf Coast continental margin, in M. P. A. Jackson, D. G. Roberts, and S. Snelson, eds., Salt tectonics: A global perspective: AAPG Memoir $65,109-151$.

Fiduk, J.C., and M.G. Rowan, 2012, Analysis of folding and deformation within layered evaporites in Blocks BM-S-8 \& -9, Santos Basin, Brazil, in G.I. Alsop, S.G. Archer, A.J. Hartley, N.T. Grant, and R. Hodgkinson, eds., Salt tectonics, sediments and prospectivity: Geological Society of London Special Publications, 363, 471-487.

Gansser, A., 1992, The enigma of the Persian salt-dome inclusions: Eclogae Geologicae Helvetiae, 85, $825-846$.

Hazzard, R. T., W. C. Spooner, and B. W. Blanpied, 1947, Notes on the stratigraphy of the formations which underlie the Smackover Limestone in south Arkansas, northeast Texas, and north Louisiana: Shreveport Geological Society, Reference Report on Certain Oil and Gas Fields of North Louisiana, South Arkansas, Mississippi and Alabama, vol. II, 483-503.

Hilchie, D.W. (1968). Caliper Logging - theory and practice. The Log Analyst, 9 (1), p. 3-12. 
Hoetz, G., J. Steenbrinkl, N. Bekkers, A. Vogelaar, and S. Luthi, 2011, Salt-induced stress anomalies: an explanation for variations in seismic velocity and reservoir quality: Petroleum Geoscience, 17, 385396.

Hudec, M.R., and M.P.A. Jackson, 2007, Terra infirm: understanding salt tectonics: Earth-Science Reviews, 82, 1-28.

Hudec, M.R., and M.P.A. Jackson, 2011, The salt mine: A digital atlas of salt tectonics, Vol. 5, p. 99. Bureau of Economic Geology.

Hudec, M. R., M. P. A. Jackson, and F. J. Peel, 2013a, Influence of deep Louann structure on the evolution of the northern Gulf of Mexico: AAPG Bulletin, 97, 1711-1735.

Hudec, M. R., I. O. Norton, M. P. A. Jackson, and F. J. Peel, 2013b, Jurassic evolution of the Gulf of Mexico salt basin: AAPG Bulletin, 97, 1683-1710.

Humphris, C. C., Jr., 1978, Salt movement on continental slope, northern Gulf of Mexico, in A. H. Bouma, G. T. Moore, and J. M. Coleman, eds., Framework, facies, and oil-trapping characteristics of the upper continental margin: AAPG, vol. 7, of, Studies in Geology, 69-86.

Jackson, C.A-L, Rodriguez, C.R., Rotevatn, A., and Bell R.E., 2014, Geological and geophysical expression of a primary salt weld: An example from the Santos Basin, Brazil: Interpretation, Vol: 2, Pages: SM77-SM89.

Jackson, C.A-L., Jackson, M.P.A., Hudec, M.R., and Rodriguez, C.R., 2015, Enigmatic structures within salt walls of the Santos Basin-Part 1: Geometry and kinematics from 3D seismic reflection and well data. Journal of Structural Geology, 75, 135-162.

Jackson, M.P.A., and C. Cramez, 1989, Seismic recognition of salt welds in salt tectonic regimes: Proceedings of the GCSSEPM Foundation 10th Annual Bob F. Perkins Research Conference, 66-71.

Jackson, M.P.A., and Hudec, M.R., 2017. Salt Tectonics: Principles and Practice. Cambridge University Press.

Kent, P.E., 1979, The emergent Hormuz salt plugs of southern Iran: Journal of Petroleum Geology, 2, $117-144$. 
Koyi, H., 2001, Modeling the influence of sinking anhydrite blocks on salt diapirs targeted for hazardous waste disposal: Geology, 29, 387-390.

Koyi, H., and Schott, B., 2000, The rise and fall of denser blocks within salt diapirs: Bollettino di Geofisica teorica ed applicata, 42, 64-66.

Kneller, E.A., and Johnson, C.A., 2011, Plate kinematics of the Gulf of Mexico based on integrated observations from the Central and South Atlantic: Gulf Coast Association of Geological Societies Transactions, 61, 283-300.

Kupfer, D.H., 1968, Relationship of internal and external structure of salt domes. In: J. Braunstein, and G.D. O'Brien, eds., Diapirism and diapirs: AAPG Memoir, 8, 79-89.

Lawton, T.F., and Amato, J.M., (2017) U-Pb ages of igneous xenoliths in a salt diapir, La Popa basin: Implications for salt age in onshore Mexico salt basins: Lithosphere, 9, 745-758.

Liro, L., and S.M. Holdaway, 2011, Salt welds in the deepwater Gulf of Mexico - Uncertainties in the amount of remnant salt: seismic and well examples: AAPG Abstracts with Programs, 986760, p113.

Peel, F. J., C. J. Travis, and J. R. Hossack, 1995, Genetic structural provinces and salt tectonics of the Cenozoic offshore U.S. Gulf of Mexico: A preliminary analysis: AAPG Memoir, 65, 153-175.

Pilcher, R.S., Kilsdonk, B. and Trude, J., 2011. Primary basins and their boundaries in the deep-water northern Gulf of Mexico: Origin, trap types, and petroleum system implications. AAPG bulletin, 95(2), pp.219-240.

Pindell, J., and J.F. Dewey, 1982, Permo-Triassic reconstruction of western Pangea and the evolution of the Gulf of Mexico/Caribbean region: Tectonics, 1, 179-211.

Richter-Bernburg, G., 1980, Salt domes in northwest Germany: Centres de Recherches ExplorationProduction, Bulletin, Elf Aquitaine, 4, 373-393.

Rider, M. and Kennedy, M. (2011). The Geological Interpretation of Well Logs (3rd ed.). Rider-French Consulting Ltd, Scotland.

Rowan, M.G., 1995, Structural styles and evolution of allochthonous salt, central Louisiana outer shelf and upper slope, in M. P. A. Jackson, D. G. Roberts, and S. Snelson, eds., Salt tectonics: A global 
perspective: AAPG Memoir 65, 199-228.

Rowan, M.G., 2004, Do salt welds seal? Proceedings of the GCSSEPM Foundation 24th Annual Bob F. Perkins Research Conference (Salt-Sediment Interactions and Hydrocarbon Prospectivity: Concepts, Applications, and Case Studies for the 21st Century), 390-403.

Rowan, M.G., Lawton, T.F., Giles, K.A., 2012, Anatomy of an exposed vertical salt weld and flanking strata La Popa Basin, Mexico. in G.I. Alsop, S.G. Archer, A.J. Hartley, N.T. Grant, and R. Hodgkinson, eds., Salt tectonics, sediments and prospectivity: Geological Society of London Special Publications, $363,33-57$.

Salvador, A., 1987, Late Triassic-Jurassic paleogeography and origin of Gulf of Mexico Basin: AAPG Bulletin, 71, 419-451.

Strozyk, F., H. Van Gent, J.L. Urai, and P.A. Kukla, 2012, 3D seismic study of complex intra-salt deformation: An example from the Upper Permian Zechstein 3 stringer, western Dutch offshore, in G.I. Alsop, S.G. Archer, A.J. Hartley, N.T. Grant, and R. Hodgkinson, eds., Salt tectonics, sediments and prospectivity: Geological Society of London Special Publications, 363, 489-501.

Theys, P. (1999). Log Data Acquisition and Quality Controls (2nd ed.). Editions Technip, Paris

Van Gent, H., J.L. Urai, and M. de Keijzer, 2011, The internal geometry of salt structures - a first look using 3D seismic data from the Zechstein of the Netherlands: Journal of Structural Geology, 33, 292311.

Wagner III, B.H., 2010, An analysis of salt welding: Unpublished PhD dissertation, University of Texas at Austin, 218pp.

Wagner III, B.H., and M.P.A. Jackson, 2011, Viscous flow during salt welding: Tectonophysics, 510, 309-326.

\section{FIGURE CAPTIONS}

Fig. 1. (A) Simplified map showing the location of the study area. (B) Broadly NNW-trending geoseismic profile (after Pilcher, et al. 2011) showing the approximate structural position and tectonostratigraphic context of the study area. Note that this line lies c. $50 \mathrm{~km}$ west of the study area (see Fig. 1A). $p=$ primary weld; $t=$ tertiary weld. TMM=top Middle Miocene; TPL=top Pliocene. 
Fig. 2. (A) base salt depth map; (B) top salt depth map; (C) salt isopach; (D) post-salt isopach; and (E) a simplified salt-tectonic features map. 1-5 in (D) refer to minibasins described in the text. Stratigraphic position of mapped seismic horizons in (A) and (B) are shown in Fig. 3.

Fig. 3. Broadly E-trending seismic profiles through the (A) north, (B) centre, and (C) south of the study area. Locations of profiles are shown in Fig. 2E. (B) intersects the studied salt weld and borehole AT8 \#1 ST; (D) Broadly N-trending seismic profiles in the (D) west and (E) east of the study area. (D) and (E) intersect postulated salt feeders (Fig. 2E), with (E) also intersecting the studied salt weld and borehole AT-8 \#1 ST. F=feeder; p=primary weld; s=secondary weld; t=tertiary weld. The locations of Fig. $6 \mathrm{~A}$ and $\mathrm{B}$ are shown in (B) and (E), respectively. The seismic polarity convention used for these seismic profiles and those in Fig. 7 are shown in (A).

Fig. 4. (A) Well-log and lithology data from the depth interval 4300-4500 $\mathrm{m}$ in AT-8 \#1 ST. The entire non-evaporitic sedimentary succession shown here is Upper Pliocene. Note the halite-rich character of the weld. For location of borehole, see Figs 2, 3B and D. (B) Details of the well-log expression of interval 4400-4450 in AT-8 \#1 ST. The weld and the main lithological subdivisions are indicated, with the colour-coded text referring to the colours in Fig. 5.

Fig. 5. Neutron-density cross-plot of petrophysical data from the depth interval $4300-4500 \mathrm{~m}$ in AT-8 \#1 ST. Note the distinct expression of intra-weld halite, which is characterised by significantly lower neutron values than underlying or overlying clastics.

Fig. 6. Compilation of biostratigraphic data from borehole AT-8 \#1 ST showing the age of sub- and suprasalt strata flanking the studied salt weld. Raw data are shown in Supplementary Material 2, with these data calibrated to the chart shown in Supplementary Material 3.

Fig. 7. (A) N-trending seismic profile (IL44638) through borehole AT-8 \#1 ST; (B) E-trending profile (XL6602) through borehole AT-8 \#1 ST. Both profiles illustrate the seismic character of the salt weld and adjacent stratigraphy. Note the distinctly chaotic seismic facies directly underlying the weld. The location of (A) is shown in Fig. 3B and the location of (B) in Fig. 3E.

Supplementary Material 1 - Uninterpreted versions of seismic profiles shown in Fig. 3.

Supplementary Material 2 - Table of biostratigraphic data from borehole AT-8 \#1 ST. Reports 1-3 are assumed to reflect different analysis of the recovered core material that may, in certain instances, be from the same depth, but which may describe different fauna; e.g. $14310 \mathrm{~m}$ in Report 1 (Globoquadrina 
altispira) and 2 (Globorotalia menardii, coiling change left/right), which both yield an Upper Pliocene age, and $8160 \mathrm{~m}$ in Report 1 (Gephyrocapsa aperta acme) and 2 (Stilostomella antillea), which both yield a Lower Pleistocene age.

Supplementary Material 3 - Gulf of Mexico biostratigraphic chart from the Bureau of Ocean Energy Management (BOEM), Regulation and Enforcement from the United States Department of Interior (https://www.data.boem.gov/Paleo/Files/biochart.pdf. Webpage accessed 15th November 2017.

Supplementary Material 4 - Uninterpreted versions of seismic profiles shown in Fig. 7. 
Fig. 1
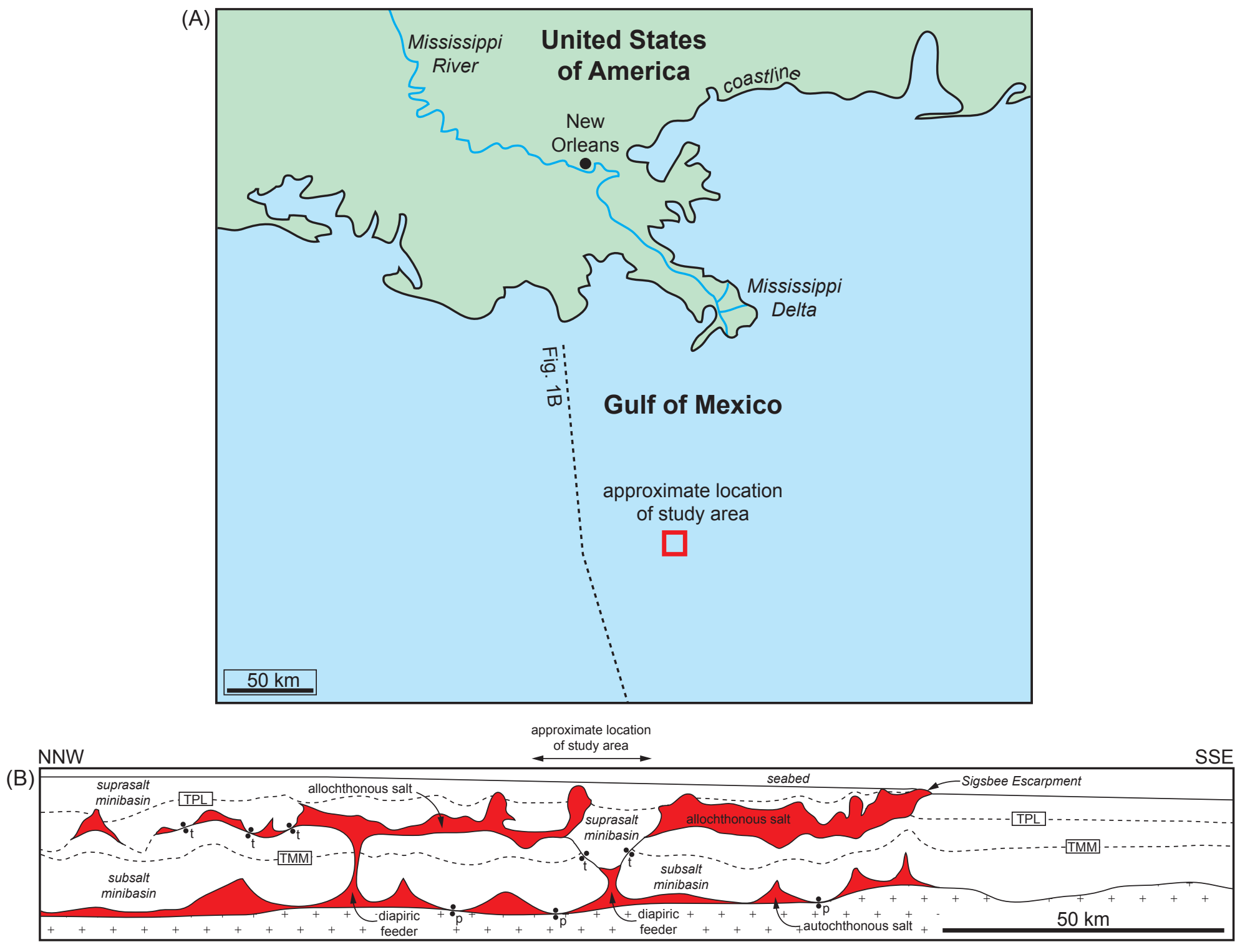
Fig. 2
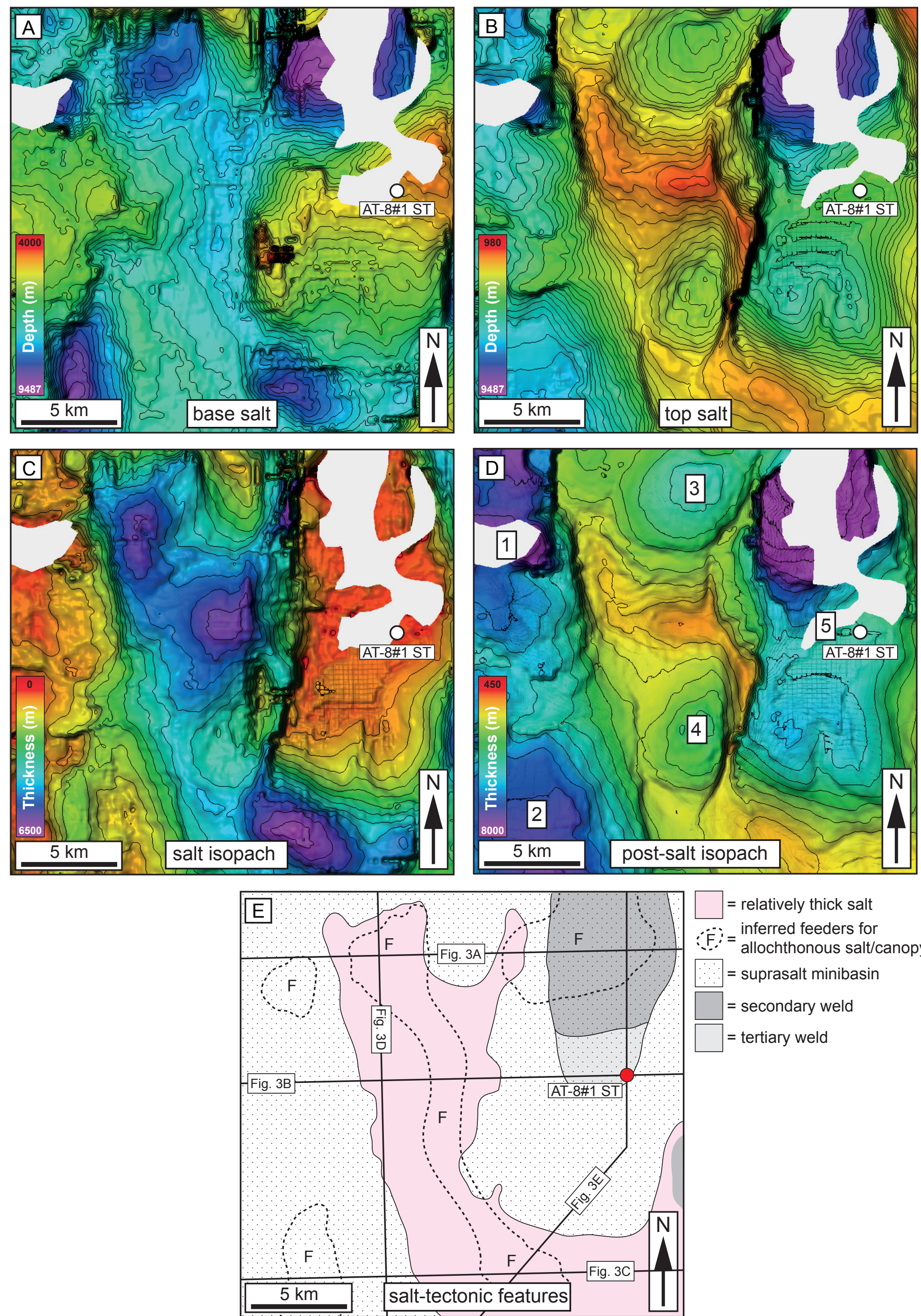

$=$ relatively thick salt

$\therefore \bar{i}$ = inferred feeders for

$\because \mathrm{F}^{\prime}=$ allochthonous salt/canopy

$\therefore=$ suprasalt minibasin

= secondary weld

$=$ tertiary weld 

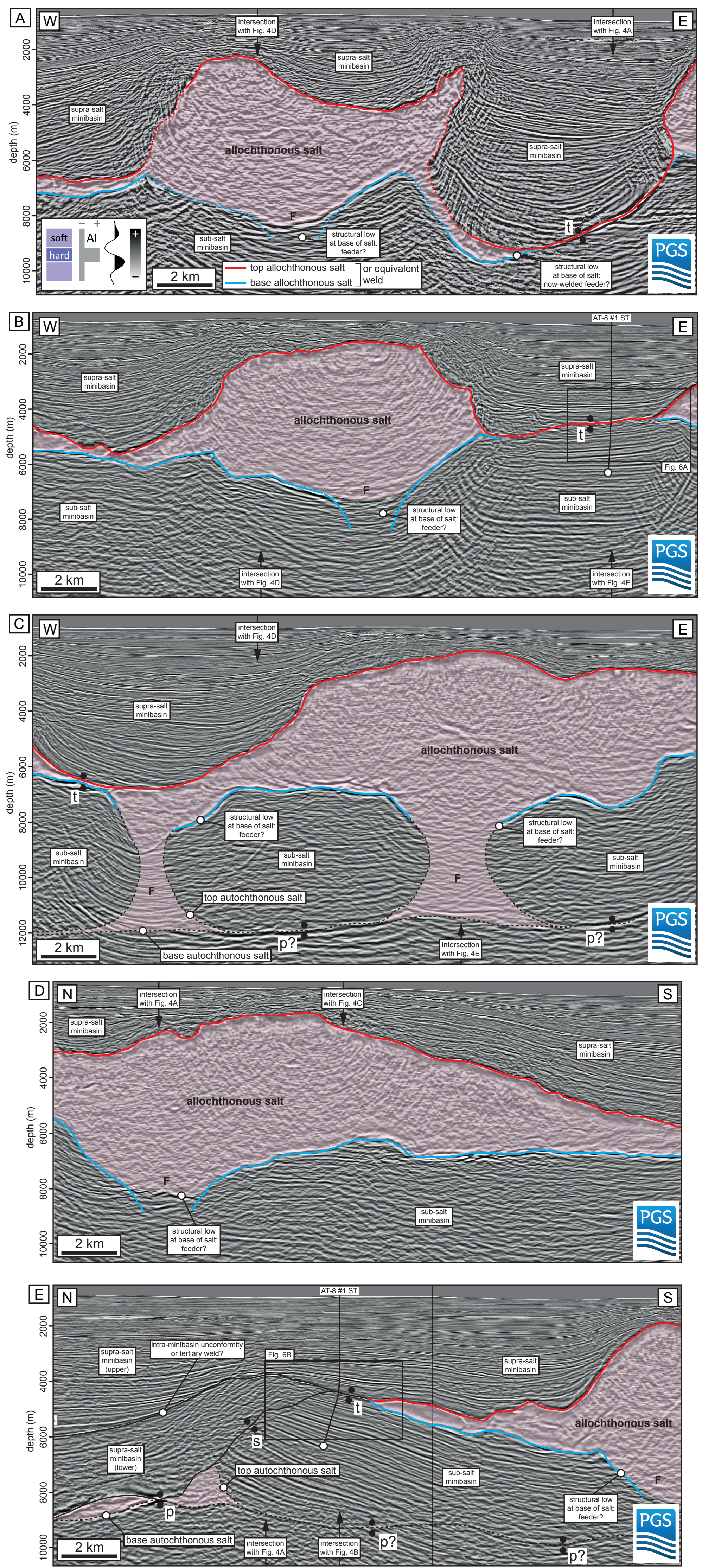
Fig. 4
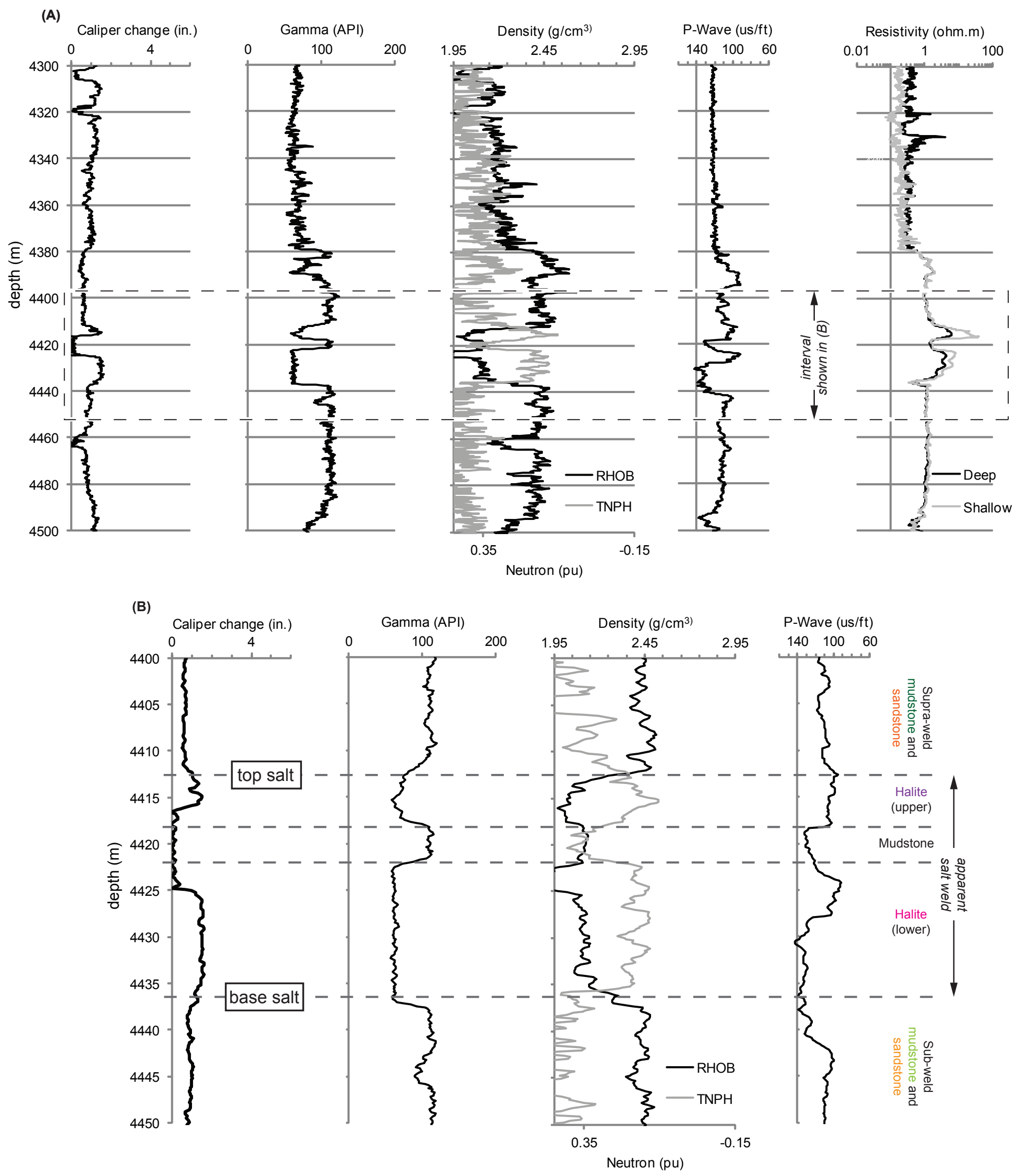
Fig. 5

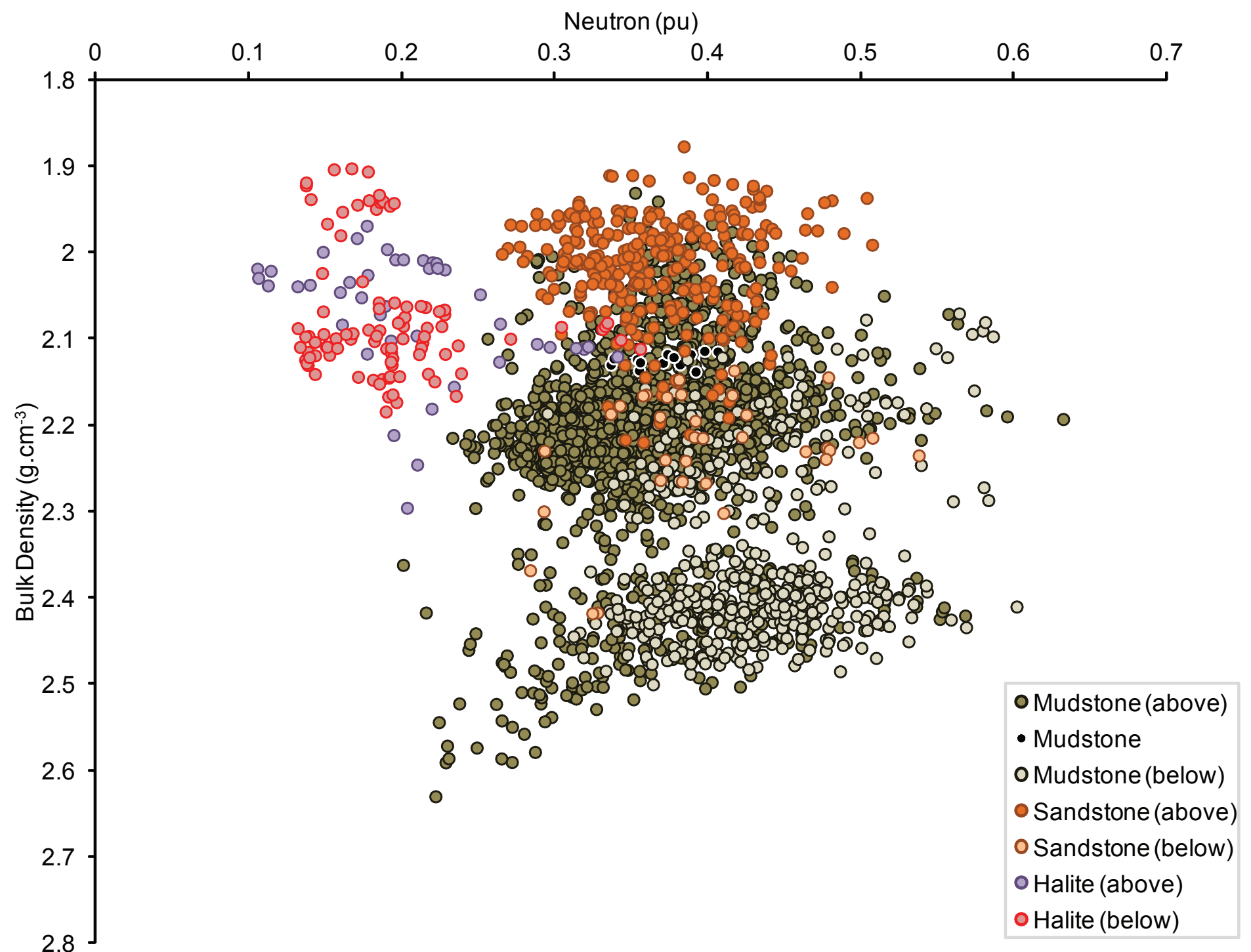


Fig. 6

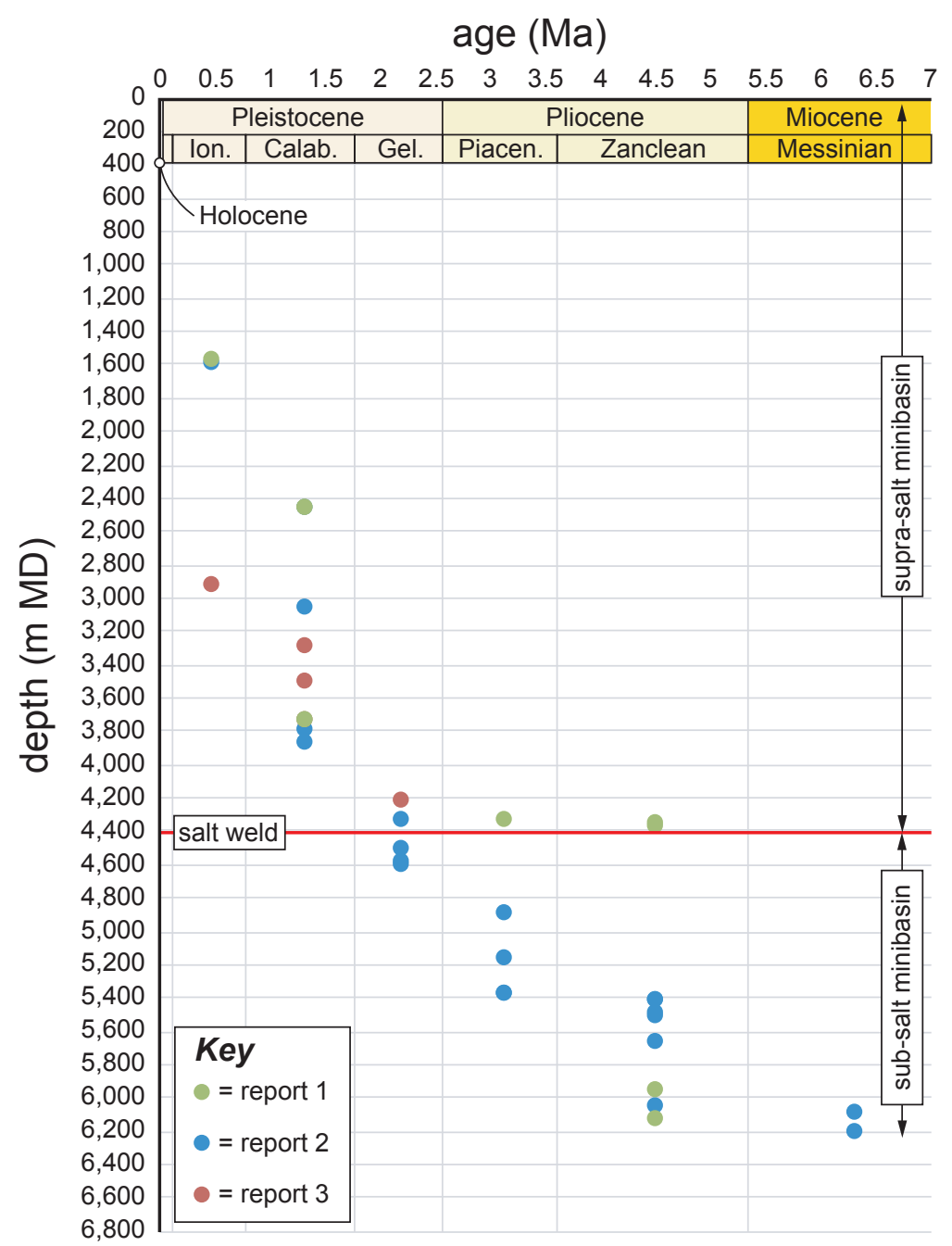


Fig. 7
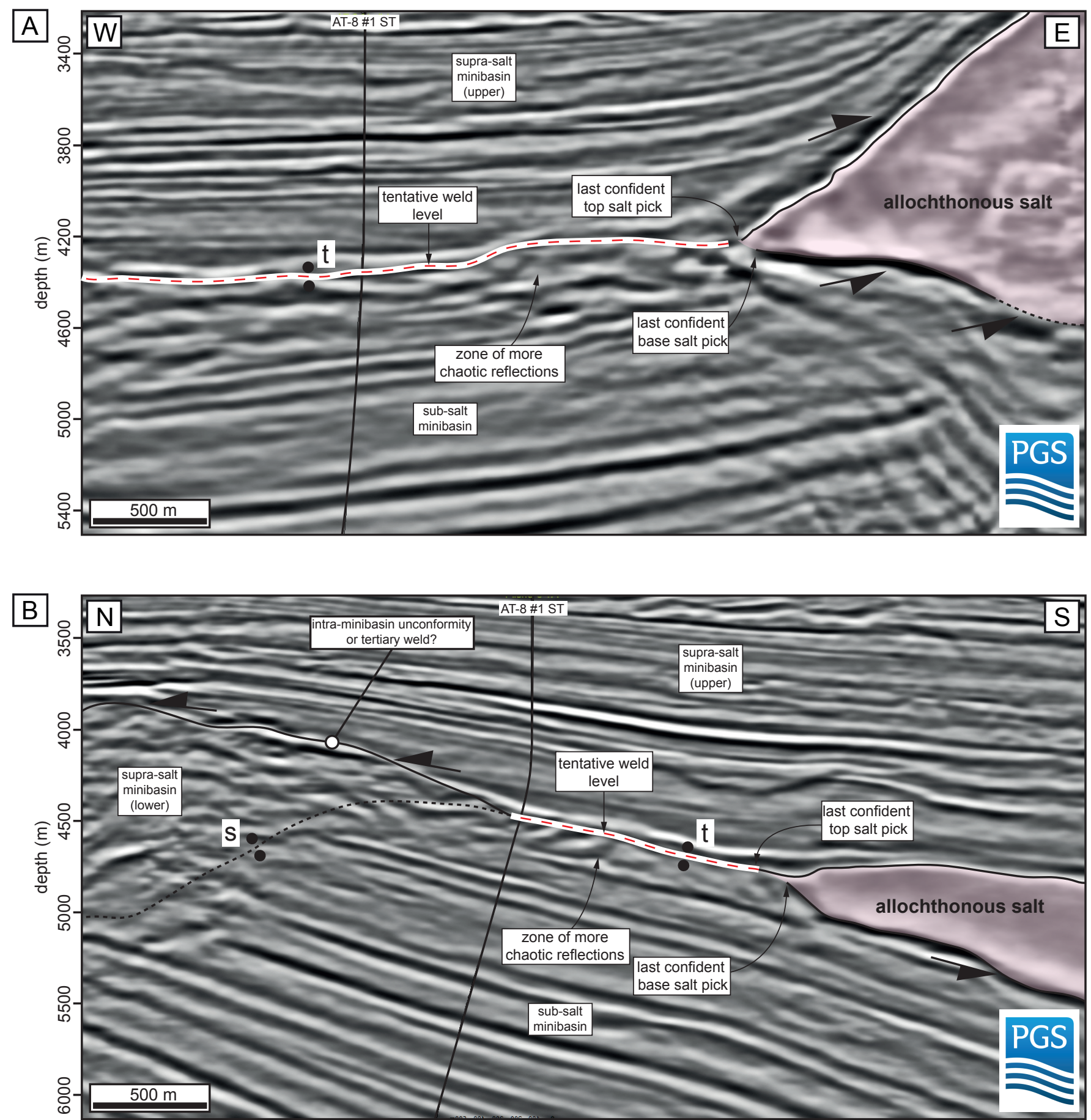

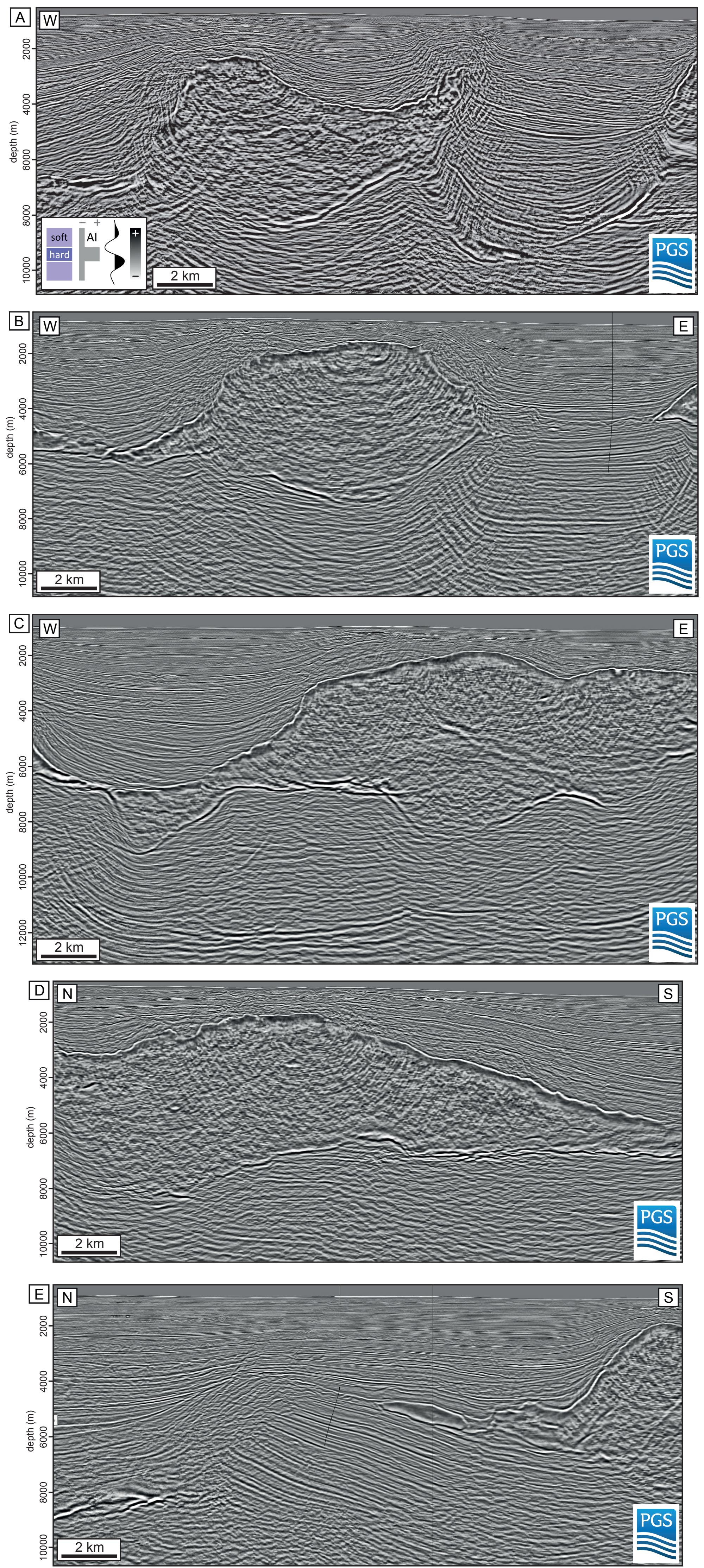
Supplementary Material 2

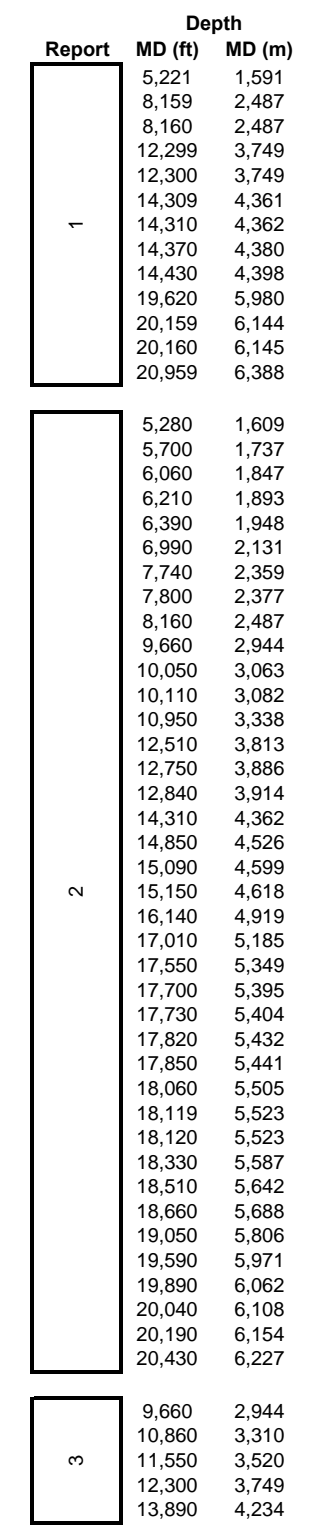

Pick Confidence

POS
DEF

DEF

DEF

POS

DEF

DEF
DEF
POS

POS

POS

DEF

DEF
DEF
DEF

DEF

DEF

DEF
DEF

DEF
DEF

DEF

DEF

DEF
DEF

DEF

DEF

POS
POS

DEF

POS

DEF

DEF
DEF

DEF

DEF
DEF
DEF
DEF

DEF

DEF
DEF

DEF

DEF

POS
DEF

DEF

DEF
DEF
DEF

DEF=definite
POS=possible

\begin{tabular}{|c|c|c|c|c|}
\hline \multicolumn{2}{|c|}{ Biostratigraphic markers } & \multicolumn{2}{|l|}{ Age } & \multirow{7}{*}{ Notes } \\
\hline \multirow{6}{*}{$\begin{array}{l}\text { Foraminefera } \\
\text { Globorotalia flexuosa }\end{array}$} & Nannoplankton & Series & Stage & \\
\hline & & Upper Pleistocene & Ionian & \\
\hline & Pseudoemiliania lacunosa "C" (acme) & $\begin{array}{l}\text { Lower Pleistocene } \\
\text { Lente }\end{array}$ & Calabrian & \\
\hline & Gephyrocapsa aperta (acme) & $\begin{array}{l}\text { Lower Pleistocene } \\
\text { Lenten }\end{array}$ & Calabrian & \\
\hline & Helicosphaera sellii & Lower Pleistocene & Calabrian & \\
\hline & & & & \\
\hline \multirow[t]{6}{*}{ Sloboquadrina altispira } & & Upper Pliocene & Piacenzian & \\
\hline & Sphenolithus abies & Lower Pliocene & $\begin{array}{l}\text { Zlanclian } \\
\text { Zann }\end{array}$ & \\
\hline & Reticulofenestra pseudoumbilica & Lower Pliocene & Zanclian & \\
\hline & Dictyococcites antarcticus & Lower Pliocene & Zanclian & \\
\hline & Amaurolithus tricorniculatus & Lemer Plipcone & 7 7ondian & reworked materral \\
\hline & & & & reworked material \\
\hline \multirow[t]{6}{*}{ Globorotalia flexuosa } & & Upper Pleistocene & Ionian & \\
\hline & & & & local marker foram increase \\
\hline & & & & local marker foram increase \\
\hline & & & & local marker foram increase \\
\hline & & & & local marker foram increase \\
\hline & & & & $\begin{array}{l}\text { 10cal marker roram increase } \\
\text { transported outer shelf facies }\end{array}$ \\
\hline \multirow{2}{*}{ Stilostomella antillea } & & Lower Pleistocene & Calabrian & \\
\hline & & & & $\begin{array}{l}\text { local marker foram increase } \\
\text { local marker foram increase }\end{array}$ \\
\hline idinella dehiscens (acme "A") & & Lower Pleistocene & Calabrian & \\
\hline \multirow{2}{*}{$\begin{array}{l}\text { idinella dehiscens (acme "B") } \\
\text { Uvigerina hispida }\end{array}$} & & & & local marker foram increase \\
\hline & & $\begin{array}{l}\text { Lower Pleistocene } \\
\text { Lower Pleistocene }\end{array}$ & $\begin{array}{l}\text { Calabrian } \\
\text { Calabrian }\end{array}$ & \\
\hline menardii (coiling change leff/right) & & 1: & & reworked material \\
\hline $\begin{array}{l}\text { menaradfit (ociling change leftright) } \\
\text { libborotalia miocenica }\end{array}$ & & $\begin{array}{l}\text { Upper Pliocene } \\
\text { Unper Plincene }\end{array}$ & Gelasian & \\
\hline Sloborotalia miocenica & & Upper Pliocene & Gelasian & \\
\hline \multirow[t]{2}{*}{$\begin{array}{l}\text { Sloborotalia pertenuis } \\
\text { slons }\end{array}$} & & Upper Pliocene & Gelasian & \\
\hline & & $\begin{array}{l}\text { Upper Pliocene } \\
\text { Uuner Pliogene }\end{array}$ & $\begin{array}{l}\text { Piacenzian } \\
\text { PPaicenziann }\end{array}$ & \\
\hline icides grosseperforatus & & & & local marker foram increase \\
\hline \multirow{5}{*}{$\begin{array}{l}\text { Arenaceous fauna } \\
\text { Cibicides marsi } \\
\text { sloborotalia margaritae } \\
\text { Uvigerina rustica }\end{array}$} & & Upper Pliocene & Piacenzian & \\
\hline & & Upper Pliocene & Piacenzian & \\
\hline & & $\begin{array}{l}\text { Lower Pliocene } \\
\text { ower Pliocene }\end{array}$ & Zanclian & \\
\hline & & $\begin{array}{l}\text { Lower Pliocene } \\
\text { Lowen }\end{array}$ & $\begin{array}{l}\text { Zanclian } \\
\text { Zanclian }\end{array}$ & \\
\hline & & & & reworked material \\
\hline \multirow{2}{*}{ Globigerina nepenthes } & & Lower Pliocene & Zanclian & \\
\hline & & & & $\begin{array}{l}\text { local marker foram increase } \\
\text { transported outer shelf facies }\end{array}$ \\
\hline \multirow{2}{*}{ ilina "P" / cf. schlumbergeri } & & Lower Pliocene & Zanclian & \\
\hline & & & & $\begin{array}{l}\text { local marker foram increase } \\
\text { local marker foram increase }\end{array}$ \\
\hline $\begin{array}{l}\text { aaeroidinellopsis multiloba } \\
\text { menardii (coiling change right/left) }\end{array}$ & & Lower Pliocene & $\begin{array}{l}\text { Zanclian } \\
\text { Messinian }\end{array}$ & \\
\hline \multirow{5}{*}{ rotalia margaritae primitiva } & & Upper Miocene & Messinian & \\
\hline & & Upper Pleistocene & & \\
\hline & Scyphosphaera pulcherima & Lower Pleistocene & Calabrian & \\
\hline & Calcidiscus macintyrei & Lower Pleistocene & Calabrian & \\
\hline & $\begin{array}{l}\text { Helicosshaera sellii } \\
\text { Discoaster brouweri }\end{array}$ & $\begin{array}{l}\text { Lower Pleistocene } \\
\text { Upper Pliocene }\end{array}$ & $\begin{array}{l}\text { Calabrian } \\
\text { Gelasian }\end{array}$ & \\
\hline
\end{tabular}




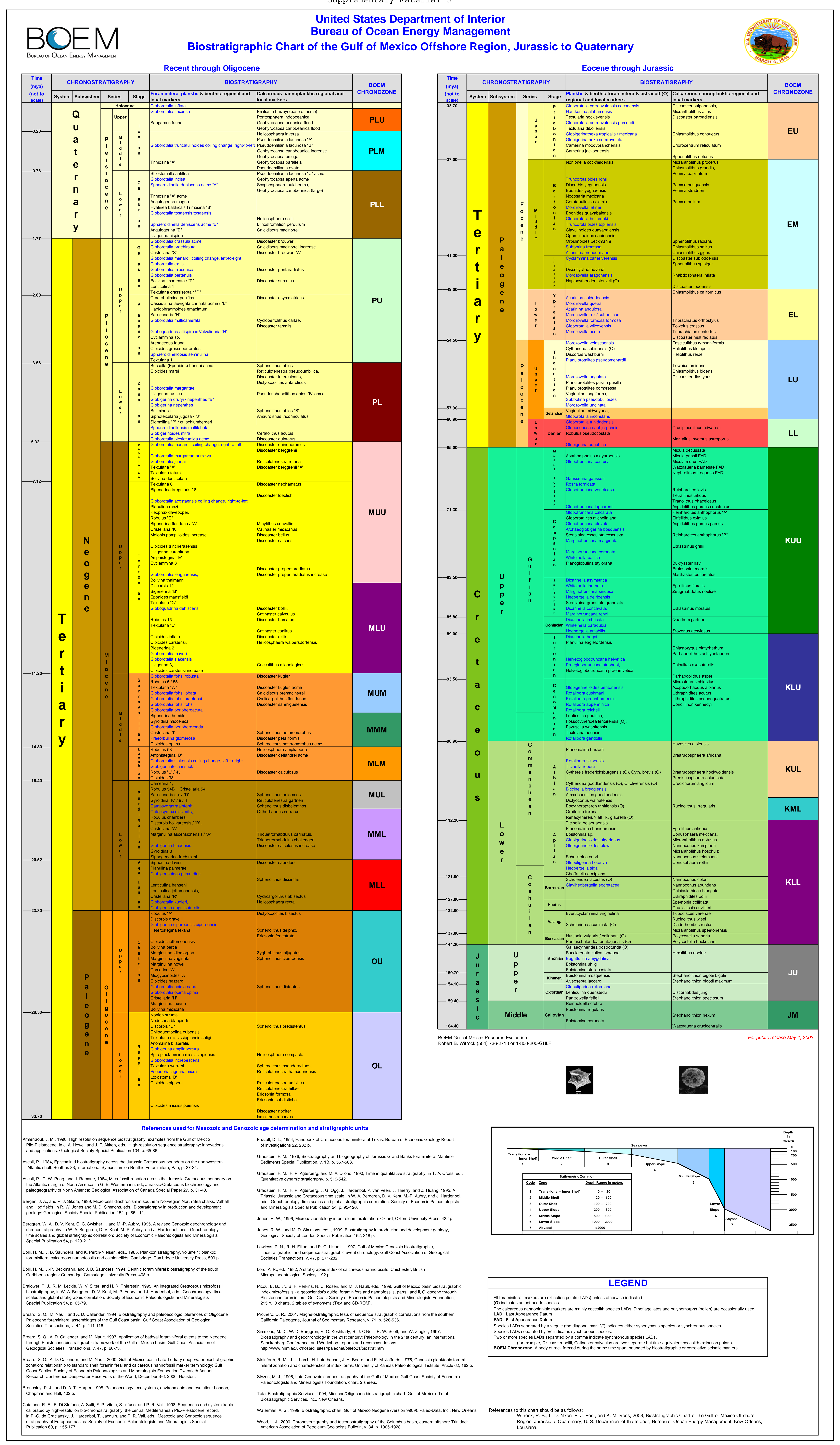


Supplementary Material 4
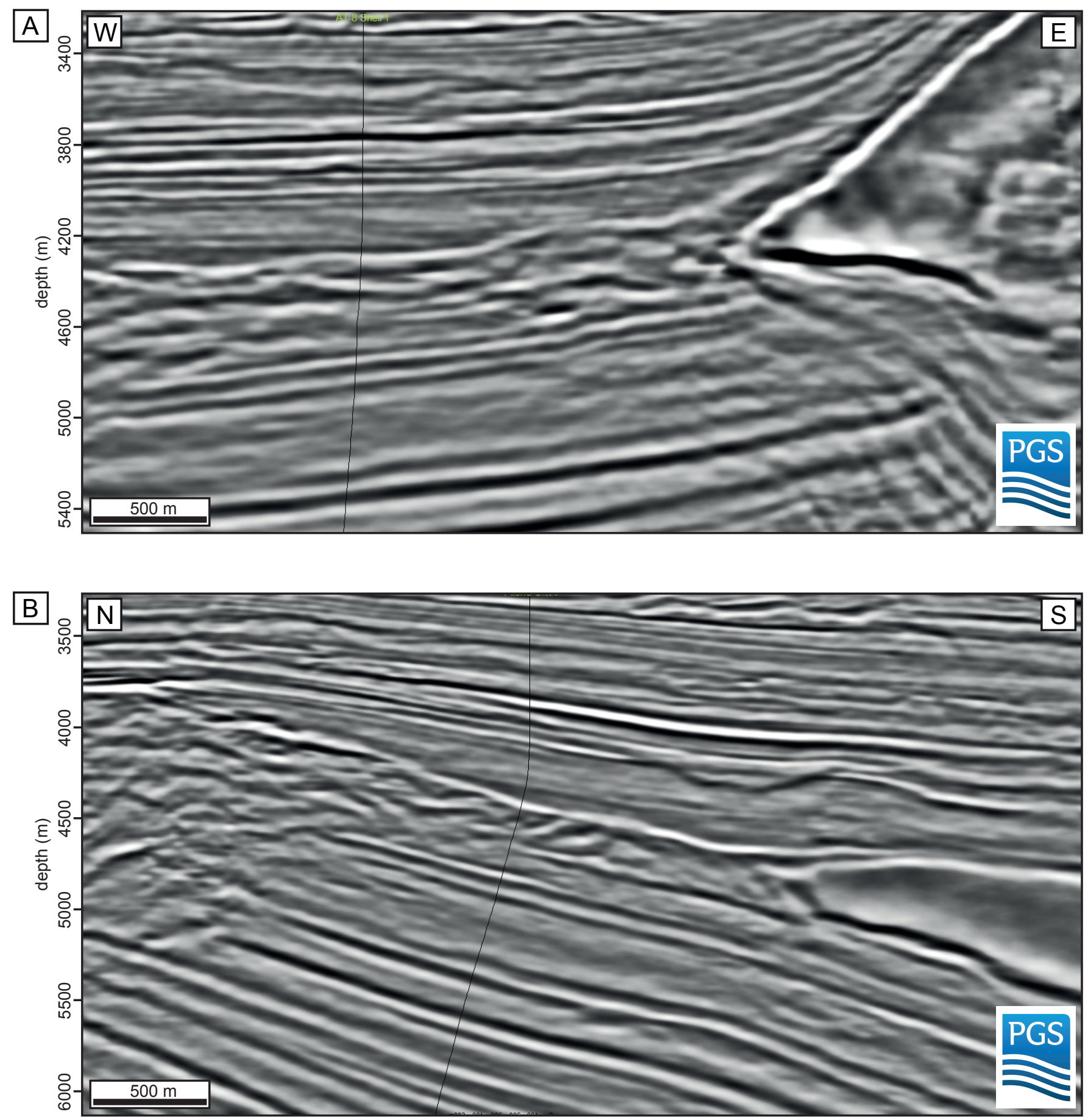